\title{
A Longitudinal Study of Language Development and School Performance in Late-Talkers at Three and Seven Years of Age
}

\author{
Gyung-Hun Hong, Suhyang Lee, Soo-Jin Kim \\ Department of Communication Disorders, Korean Nazarene University, Cheonan, Korea
}

Correspondence: Suhyang Lee, PhD Department of Communication Disorders, Korea Nazarene University, 48 Wolbong-ro, Seobuk-gu, Cheonan 31172, Korea

Tel: $+82-41-570-1465$

Fax: +82-41-570-7849

E-mail: suhyang@kornu.ac.kr

Received: October 1, 2018

Revised: November 7, 2018

Accepted: November 19, 2018

This work was supported by the research fund of Korea Nazarene University in 2018.
Objectives: The study investigated the prevalence of late-talkers at the age of 3 and followed up the language development and school performance of these children at the age of 7 in comparison with those without a history of speech delay. Methods: The participants were 1,342 children who were part of the Panel Study on Korean Children. The participants were divided into late talkers (LT) and typically developing children (TD) groups based on expressive vocabulary scores (Receptive \& Expressive Vocabulary Test [REVT]) conducted at the age of three. REVT and school performance of the two groups were then re-measured and compared at age 7. MANCOVA analysis was conducted to analyze the difference between LT and TD children. Results: The results were as follows: the prevalence of late-talkers at the age of 3 was $16.6 \% ; 31.4 \%$ of $L T$ and $10.1 \%$ of TD children scored below the $10 \%$ tile in expressive vocabulary at the age of 7 ; and language development and language performance (reading, writing, speaking, listening) scores at the age of 7 in LT were significantly lower than TD. Conclusion: The study suggests that a delay in early expressive vocabulary development can be a cause for poor language development and school performance. Given this, language intervention should be considered early on for late-talkers to help overcome potential deficits in language development and school performance.

Keywords: Late-talker, Longitudinal study, Language development, School performance
단순언어장애나 언어장애를 부수적으로 동반한 발달장애의 경 우에 대부분 발달 초기에 첫 낱말 출현시기와 어휘량 등에서 표현 어휘 발달의 지체를 보이는 것으로 알려져 있다(Leonard, 1998; Rescorla \& Dale, 2013). 따라서 영유아기의 표현어휘 발달의 지체 는 후일 언어장애에 대한 강력한 위험요인 중 하나이다. 그럼에도 불구하고 영유아들이 다른 발달 영역에서 뚜렷한 결함 없이 표현어 휘에서만 지체를 보이는 경우에 초기 표현어휘 발달의 정상적 변이 (variation)로 간과하는 경우가 많다. 그러나 이러한 특성을 보이는 '말늦은 아동(late-talker)' 중 상당한 비율이 지속적으로 언어발달 에서 결함을 나타낼 가능성이 높은 것으로 알려져 있다. 3 세 이하 의 ‘말늦은 아동'을 종단 관찰한 국외 선행연구들은 약 $20 \%$ 안팎의 아동이 4 세 이후에도 지속적으로 문제를 보인다고 보고하고 있다 (Manhardt \& Rescorla, 2002; Rescorla, Dahlsgaard, \& Roberts, 2000).
현대 사회의 언어중재의 개념은 현재 나타난 문제의 개선이나 소 거의 개념을 넘어서 미래에 올 수 있는 문제의 예방이라는 측면을 포함한다(Rescorla \& Dale, 2013). 이러한 점을 고려할 때 언어발달 에 문제가 있는 영유아들의 조기 언어중재(early language intervention)는 후일에 초래될 수 있는 심각한 언어문제나 다른 발달적 문제들의 발현을 차단하거나 그 정도를 경감시키는 예방적 측면에 서도 매우 중요하다. 이러한 이유로 전문가들은 '말늦은 아동’에 대 해 가능한 이른 시기의 언어중재를 권유한다(Billeaud, 2003; Girolametto, Weitzman, Earle, Rescola, \& Dale, 2013; Rossetti, 2001; Shin \& Lee, 2015).

이처럼 '말늦은 아동'의 조기 언어중재의 중요성이 강조되고 있 음에도 양육자나 전문가가 적극적인 조기중재를 결정하는 것은 쉬 운 일은 아니다. 실제로 영유아기의 조기 언어중재의 결정은 단순 
히 영유아가 나타내는 표현어휘 발달 지체 여부만으로는 판단하기 는 어렵다. 초기 표현어휘 발달의 넓은 변이뿐만 아니라 영유아 가 족이나 환경이 또한 중재 여부의 결정에서 중요하게 고려해야 할 요 인이기 때문이다. 영유아기는 특히 중재 효과를 위해선 양육자의 적극적 참여가 절대적인 시기이다(Billeaud, 2003; Girolametto et al., 2013; Kim \& Lee, 2007; Lee, 2015; Rossetti, 2001). 따라서 조기 중재는 아동뿐만 아니라 가족 구성원들의 일상이나 관계의 변화 를 가져올 수 있으며, 더불어 해당 가족이 치러야 하는 경제적, 시간 적 비용 및 가족의 심리적 고충 등에 대한 다양한 측면을 모두 고려 해야하는 문제이다. 영유아기의 자녀를 둔 많은 부모들은 자녀의 발달 문제로 전문언어재활기관을 스스로 방문했음에도 불구하고 전문적 중재를 권유받는 경우에 좌절, 걱정, 자책 등의 상당히 큰 스트레스를 받는 것으로 알려져 있다(Shipley, 1992).

'말늦은 아동'의 조기중재로 인해 야기될 수 있는 가족의 '고충' 과 '비용'에도 불구하고 적극적으로 가능한 이른 조기중재를 고려 해야 하는 가장 큰 이유는 '말늦은 아동' 집단이 나타내는 부정적 인 발달 예후 때문이다. '말늦은 아동'의 후일 예후에 대한 국외 선 행연구들은 이들이 언어뿐만 아니라 학업, 사회 및 정서 영역까지 부정적인 결과를 초래하는 것으로 제시하고 있다(Manhardt \& Rescorla, 2002; Rescorla, 2002, 2005, 2009). 이러한 부정적인 예후는 4 세 이후에 여전히 표현어휘 발달에서 지체를 나타내는 아동들만 이 아니라 표현어휘 수준이 정상 수준에 도달한 아동들 중에서도 상당수가 포함되어 있음이 보고되었다(Rescorla, 2002, 2005, 2009). 또한 '말늦은 아동'집단이 13 세 때에 어휘, 문법, 구어 기억, 읽기 이해에서 정상 수준을 나타냈으나 일반 발달 이력의 아동들 보다는 현저하게 낮은 수행 수준을 보였다(Rescorla, 2005).

국내의 경우, 우리말을 사용하는 '말늦은 아동'에 대한 연구가 여 전히 부족한 현실이다. 특히 이들의 장기간 발달적 변화를 종단적 으로 추적한 연구들은 많지 않다. Hong과 Kim (2005)은 18-30개 월 사이의 '말늦은 아동' 40 여 명을 6 개월간 추적 관찰한 결과, 약 $56 \%$ 가 여전히 표현어휘의 지체를 나타냈다고 보고한 바 있다. Kim, Lee와 Hong (2017)은 3세 '말늦은 아동'집단이 7세의 말소리 발달 에 부정적인 예후를 나타냈다는 결과를 보고하였다. 또한 Jang (2017)은 5-6세의 학령전기 언어장애 아동들이 7세에 학업수행력 과 학교적응에서 일반 발달 아동들에 비해 유의하게 낮은 수행력 을 보였다고 보고하였다. 이 두 연구결과는 3 세 이전의 언어발달 지 체가 장기적으로 학령기의 말, 언어와 학교수행력에도 부정적인 영 향을 미칠 수 있음을 간접적으로 시사한다. '말늦은 아동'의 조기 언어중재 여부를 결정함에 있어서 장기적인 종단 관찰을 통해 초 기 표현어휘 발달 지체가 후일에 미치는 영향을 분석한 정보는 양
육자와 전문가 모두에게 중요한 판단의 근거가 될 수 있다.

그러므로 본 연구는 우리말을 사용하는 3세 '말늦은 아동'의 출 현율을 제시하고, 발달초기 표현어휘 지체가 학령기의 언어 및 학 교 관련 수행력에 미치는 영향을 분석하는 데 목적이 있었다. 이를 위하여 우리나라 아동들을 대상으로 표현어휘 및 학교수행력을 조 사한 한국아동패널의 전국 단위의 대규모 종단 자료를 사용하여 3 세의 ‘말늦은 아동'의 비율을 분석하고, '말늦은 아동' 집단과 ‘일반 발달 아동' 집단이 7세 때에 나타낸 표현어휘 발달 수준을 분석하 였으며, 또한 두 집단이 학교수행력 관련 변인들에서 나타낸 수준 을 비교 분석하였다.

\section{연구방법}

\section{연구대상}

본 연구의 대상자는 육아정책연구소의 한국아동패널이 2011년 (4차년도)과 2015년(8차년도)에 수집한 종단 자료에서 추출하였다. 한국아동패널은 우리나라 아동의 발달특성과 양육실태, 육아지원 기관의 기능 및 지역사회와 육아정책의 영향 등에 대한 국가 차원 의 자료 수집을 위하여 2008년(1차년도)에 신생아를 시작으로 1 년 단위로 2027년까지 전국 단위의 종단 자료 수집을 진행하고 있다 (http://panel.kicce.re.kr). 현재 진행한 자료 중 4차년도와 8차년도 에 수용·표현어휘력검사(Receptive Expressive Vocabulary Test, REVT; Kim, Hong, Kim, Jang, \& Lee, 2009)를 사용하여 아동들의 언어발달 수준을 측정하였다. 4 차년도 자료에서 REVT의 점수 산 출이 가능한 아동의 수는 총 1,754 명이었으며, 이들 중에서 8 차년 도에도 REVT의 점수 산출이 가능한 총 1,342 명이었다. 따라서 4 차 년도와 8 차년도에서 공통으로 REVT 점수산출이 가능했던 1,342 명을 본 연구 대상자로 포함하였다(Table 1).

\section{검사도구}

REVT

REVT (Kim et al., 2009)는 만 2세 6개월 영유아부터 만 16세 이 상 성인을 대상으로 수용 및 표현어휘 능력을 측정하는 한국의 표 준화된 어휘검사이다. 수용과 표현어휘검사를 별도로 실시하며, 그 림자료를 사용한다. 수용어휘검사는 검사자가 들려준 단어를 듣고

Table 1. Participants' information

\begin{tabular}{lccc}
\hline & Boy & Girl & Total \\
\hline No. of children (\%) & $689(51.3)$ & $653(48.7)$ & $1,342(100)$ \\
Age (mo) & $38.20 \pm 1.45$ & $38.26 \pm 1.43$ & $38.23 \pm 1.44$ \\
\hline
\end{tabular}

Values are presented as mean \pm SD. 
피검사자가 4 개의 보기 그림 중에서 해당 보기를 선택하도록 하며, 표현어휘검사는 검사자의 질문을 듣고 피검사자가 그림이 나타내 는 단어를 말하도록 하는 방법을 사용한다. 수용 및 표현어휘 영역 에서 각각 연령집단별 평균, 표준편차, 백분위 등의 연령별 규준을 제공한다. 본 연구에서는 REVT의 표현어휘의 백분위(이하 \%ile) 점수를 ‘말늦은 아동’의 선정 기준으로 사용하였다.

\section{한국아동패널 질문지}

'한국아동패널 4차(2011년도) 질문지'를 사용하여 3세 아동들의 기본 배경 변인들(모의 학력, 부의 학력, 가정의 월평균소득, 아동 의 수용어휘 백분위점수, 출생 순위, 아동 연령)을 분석하였으며, '한국아동패널 8차(2015년도) 질문지(http://panel.kicce.re.kr/kor/ publication/01.jsp)'를 사용하여 7세의 학교수행력 관련 변인들을 분석하였다. 질문지는 응답대상별로 어머니, 아버지, 아동, 교사 대 상의 질문들로 구성되어 있다. 아동 관련 문항의 경우, 2011년도에 는 REVT를 실시하였고, 2015년에는 REVT, 자아존중감, 전반적 행복감, 학교생활, 미래기대의 범주에 관련한 문항들이 포함되어 있다. 교사 응답 질문의 경우, 2011년도에는 기관의 특성, 아동의 기 관 생활 특성의 범주 문항들이 포함되었으며, 2015년도에는 집행기 능, 학업수행능력, 학교적응, 교사와 학교 관련 범주의 문항들이 추 가되었다.

\section{자료수집}

한국아동패널은 아동과 양육자에 대한 정보를 수집하는 대면 면접과 우편용 질문지를 통한 부모조사, 아동의 교사에 대한 $\mathrm{Web}$ 조사, 그리고 REVT를 포함한 아동발달 수행검사 등을 통해 자료 를 수집하였다. 교사조사는 조사 대상 아동의 어머니에게 아동의 담임교사를 조사할 수 있는지에 대한 동의를 얻은 후, 담임교사에 게 전화하여 실시를 안내한 후 웹페이지를 통한 온라인 조사를 실 시하였다. REVT 검사는 워크숍 등을 통해 훈련받은 면접원이 아 동의 가정을 방문하여 검사하였다(Kim et al., 2016).

\section{자료분석}

본 연구의 자료분석은 우선 한국아동패널의 4 차(3세 자료)와 8 차(7세 자료) 모두에서 REVT의 점수 산출이 가능한 자료(총 1,342 명)를 추출한 후에 독립변인, 종속변인 및 가외변인을 분석하였다.

3세의 ‘말늦은 아동', 7세의 ‘표현어휘발달 지체 아동’, 3세와 7세의 '일반 발달 아동' 집단의 분류

3세의 '말늦은 아동(late-talkers, LT)' 집단은 Hong과 Kim (2005)
의 준거를 적용하여 3 세 아동(4차년도) 자료에서 REVT의 표현어 휘 발달 점수가 또래 연령집단 평균의 $10 \% \mathrm{ile}$ 미만이면서, 신경, 청 각, 인지, 정서 등의 다른 발달 영역에서는 뚜렷한 결함이 보고되지 않은 아동들이었다. 3 세의 LT 중에서 7세 때에 REVT의 표현어휘 발 달 점수가 여전히 정상수준에 미치지 못하고 또래 집단에서 $10 \% \mathrm{ile}$ 미만인 아동들은 '표현어휘발달 지체 지속 아동(persistent expressive vocabulary delay, $\mathrm{PED})$ ' 집단으로 정의하여 분류하였다. '일반 발달 아동(typical development, TD)' 집단은 3세와 7세의 각각의 집단에서 REVT의 표현어휘 발달 점수가 $10 \%$ ile 이상인 아동들로 분류하였다.

\section{학교수행력(school performance) 관련 변인 분석}

학교수행력은 일반적으로 학업 성취, 학교생활에서의 사회-정서 적응력, 의사소통 등을 포함한다(Dornbusch, Ritter, Leiderman, Roberts, \& Fraleigh, 1987; Nicholas \& Geers, 2003). 본 연구에서도 이를 참조하여, 한국아동패널의 2015년 면접 조사용 질문지 중에 서 아동의 담당교사가 평정한 아동의 학교생활과 관련된 항목들 을 사용하여 연구자가 ‘학교수행력'이란 용어로 정의하고 관련 변 인들로 '언어관련 학업수행력, ‘언어 이외 학업수행력, '집행기능' 및 '학교적응력'을 구체적인 종속변인으로 설정하였다. 각 변인명 (variable label)은 한국아동패널이 사용한 변인명을 사용하였다. 단, 한국아동패널이 조사한 변인 중에서 '학업수행력'의 항목을 '언어관련 학업수행력'과 ‘언어 이외 학업수행력’으로 구분하였다. '학업수행력'은 5 점 척도(1) 하위 $20 \%$ 이내-(5) 상위 $20 \%$ 이내)의 총 10 개의 문항으로 '언어관련 학업수행력'은 읽기, 말하기, 쓰기, 말 이해하기의 4 개 항목, '언어 이외 학업수행력'은 수세기, 덧셈, 뺄 셈, 비교(크기, 무게), 분류의 5 개 항목으로 구성되어 있다. '집행기 능'은 3점 척도(1) 전혀 아니다-(3) 자주 그렇다)의 40 개 문항(예: 무 슨 일이든 시작하기를 힘들어 한다, 목표를 세우고 목표를 달성하 기 위해 실제 행동을 하는 것을 어려워한다) 그리고 '학교적응력'은 5점 척도(1) 전혀 그렇지 않다-(5) 매우 그렇다)를 사용한 총 35개 의 문항들이었다(예: 학교에서 질서를 잘 지킨다, 정해진 규칙을 잘 지킨다). 각 변인별 점수는 해당 문항들의 평정 점수를 합산하여 산 출하였다. ‘언어관련 학업수행력, '언어 이외 학업수행력' 및 '학교 적응력'은 총점이 높을수록 긍정적 의미인 반면, ‘집행기능'은 총점 이 높을수록 부정적 의미를 반영한다. '학업적응력'의 부정적 의미 의 3개의 문항(예: 수업 중 안절부절 못하고 계속 앉아 있기 힘들다) 은 교사가 평정한 점수를 역코딩한 후(예: (1)을 (5)로 변경)에 분석 하였다. 종속변인별 관련 문항들의 예는 Appendix 1에 제시하였다. 


\section{통계처리}

통계 분석은 SPSS 22 프로그램을 사용하였다.

\section{3세 LT의 출현율 및 7 세의 표현어휘 발달 예후 형태 분석}

$\mathrm{LT}$ 의 출현율은 3 세 아동 집단을 $\mathrm{LT}$ 와 $\mathrm{TD}$ 집단으로 구분하여 집 단별 전체 및 성별 비율과 빈도를 산출하였다. 7세의 표현어휘 발달 예후 형태 분석은 3 세 $\mathrm{LT}$ 와 $\mathrm{TD}$ 집단의 아동들이 7 세의 $\mathrm{PED}$ 집단 과 $\mathrm{TD}$ 집단으로 분류된 비율과 빈도를 분석하였다. 또한 3세의 REVT 점수의 $10 \%$ ile 구간 단위별로 7세의 $\mathrm{PED}$ 와 $\mathrm{TD}$ 로 분류된 아동수를 분석하였다.

\section{7세의 학교수행력 비교분석}

3세 LT와 TD 집단을 독립변인으로 하고, 7세의 학교수행력 관련 변인들을 종속변인으로 하여 3세의 두 집단이 7세에 나타낸 학교수 행력의 점수차이가 통계적으로 유의한지를 검증하였다. 종속변인에 대한 가외변인의 영향력을 통제하기 위하여 종속변인들과 상관관계 가 높다고 알려진 3 세의 주요 환경 및 발달 요인들인 모의 학력, 부의 학력, 아동의 수용어휘 백분위점수, 아동 연령(월), 가정 월평균소득 과 종속변인 간의 상관관계를 분석하였다. 분석 결과, 유의수준 .001 에서 상관관계가 유의하게 나타난 모의 학력, 부의 학력, 수용어휘 백분위점수를 공변인으로 설정하여 다변량공분산분석(MANCO$\mathrm{VA)}$ 을 실시하였다. 공변량 분석을 위하여 수용어휘 백분위점수가 없는 자료를 분석에서 제외하였으며, 그 결과 분석에 포함된 대상자 수는 총 861 명으로 $\mathrm{LT}$ 집단이 108 명, TD 집단이 753 명이었다.

Table 2. Prevalence of $L T$ at age of 3 years

\begin{tabular}{lrrr}
\hline & LT group & TD group & \multicolumn{1}{c}{ Total } \\
\hline Boy & $132(59.2)$ & $557(49.8)$ & $689(51.3)$ \\
Girl & $91(40.8)$ & $562(50.2)$ & $653(48.7)$ \\
Total & $223(16.6)$ & $1,119(83.4)$ & $1,342(100)$ \\
\hline
\end{tabular}

Values are presented as number $(\%)$.

$\mathrm{LT}=$ late talkers; $\mathrm{TD}=$ typically developing children .

Table 3. Prevalence of expressive vocabulary delay at age of 7 years across groups at age of 3 years

\begin{tabular}{lcrrr}
\hline & At aged of & \multicolumn{3}{c}{ At aged of 7 years } \\
\cline { 3 - 5 } & 3 years & PED group & TD group & \multicolumn{1}{c}{ Total } \\
\hline LT group & $223(16.6)$ & $70(31.4)$ & $153(68.6)$ & $223(100)$ \\
TD group & $1,119(83.4)$ & $113(10.1)$ & $1,006(89.9)$ & $1,119(100)$ \\
Total & $1,342(100)$ & $183(13.6)$ & $1,159(86.4)$ & $1,342(100)$ \\
\hline
\end{tabular}

Values are presented as number $(\%)$.

$\mathrm{LT}=$ late talkers; $\mathrm{TD}=$ typically developing children; $\mathrm{PED}=$ persistent expressive vocabulary delayed children.

\section{연구결과}

\section{3세 LT의 출현율 분석 결과}

3세의 LT 집단의 출현율을 분석한 결과, 총 $16.6 \%$ 로 나타났으며, 남녀의 비율은 각각 $59.2 \%$ 와 $40.8 \%$ 로 남아가 여아보다 많았다(Table 2).

\section{3세 LT와 TD의 7세 표현어휘 발달 예후 분석 결과}

3 세에 LT와 TD 집단이었던 대상자들이 7세에 나타낸 표현어휘 점수를 분석한 결과, $\mathrm{LT}$ 집단의 223 명 중 $31.4 \%$ 인 70 명의 아동들이 7세에 여전히 표현어휘의 발달이 $10 \%$ ile 미만인 PED 집단으로 분 류되었으며, $68.6 \%$ 인 153 명이 $10 \%$ ile 이상인 일반 발달 수준에 도 달한 것으로 나타났다. 반면에 3 세의 TD 집단인 1,119 명 중에서 $10.1 \%$ 인 113명이 7세에 PED로 분류되었다(Table 3). 7세의 PED 아 동이 3 세 때에 나타낸 표현어휘 발달 수준을 분석하기 위하여, 표현

Table 4. Distribution of PED and TD across percentiles of expressive vocabulary scores

\begin{tabular}{lccr}
\hline & \multicolumn{2}{c}{ At aged of 7 years } & \\
\cline { 2 - 3 } & PED group & TD group & \\
\hline $\begin{array}{l}\text { Percentile of expressive vocabulary scores } \\
\text { at age of 3 years }\end{array}$ & & & \\
$<10$ & $70(38.3)$ & $153(13.2)$ & 223 \\
$10-19$ & $39(21.3)$ & $180(15.5)$ & 219 \\
$20-29$ & $25(13.7)$ & $153(13.2)$ & 178 \\
$30-39$ & $11(6)$ & $108(9.3)$ & 119 \\
$40-49$ & $8(4)$ & $82(7.1)$ & 90 \\
$50-59$ & $5(2.7)$ & $46(4)$ & 51 \\
$60-69$ & $6(3.3)$ & $79(6.8)$ & 85 \\
$70-79$ & $6(3.3)$ & $104(9)$ & 110 \\
$80-89$ & $7(3.8)$ & $108(9.3)$ & 115 \\
$90-99$ & $4(2.2)$ & $113(9.7)$ & 117 \\
100 & $2(1.1)$ & $33(2.8)$ & 35 \\
Total & 183 & 1,159 & 1,342 \\
\hline
\end{tabular}

Values are presented as number (\%).

$\mathrm{TD}=$ typically developing children; $\mathrm{PED}=$ persistent expressive vocabulary delayed children.

Table 5. Descriptive statistics of school performance variables

\begin{tabular}{lcc}
\hline & LT group & TD group \\
\hline Language performance & $16.07 \pm 4.14$ & $16.77 \pm 3.78$ \\
Other academic performance & $21.34 \pm 4.63$ & $21.78 \pm 4.22$ \\
School adaptability & $138.92 \pm 25.07$ & $139.81 \pm 20.3$ \\
Executive function & $52.23 \pm 16.12$ & $51.77 \pm 15.86$ \\
\hline
\end{tabular}

Values are presented as mean $\pm S D$.

$\mathrm{LT}=$ late talkers; $\mathrm{TD}=$ typically developing children. 
Table 6. Correlation of variables

\begin{tabular}{|c|c|c|c|c|c|c|c|c|}
\hline & $\begin{array}{c}\text { Other } \\
\text { performance }\end{array}$ & $\begin{array}{c}\text { School } \\
\text { adaptability }\end{array}$ & $\begin{array}{l}\text { Executive } \\
\text { function }\end{array}$ & $\begin{array}{l}\text { Maternal } \\
\text { education }\end{array}$ & $\begin{array}{l}\text { Paternal } \\
\text { education }\end{array}$ & $\begin{array}{l}\text { Family } \\
\text { income }\end{array}$ & $\begin{array}{l}\text { Age } \\
\text { of child }\end{array}$ & REVT-R \\
\hline Language performance & $.869^{*}$ & $.575^{*}$ & $-.594^{*}$ & $.157^{*}$ & $.166^{*}$ & .071 & .048 & $.283^{*}$ \\
\hline Other performance & & $.510^{*}$ & $-.565^{*}$ & $.143^{*}$ & $.148^{*}$ & .068 & .051 & $.260^{*}$ \\
\hline School adaptability & & & $-.718^{*}$ & $.117^{*}$ & $.109^{*}$ & .065 & .055 & $.135^{*}$ \\
\hline Executive function & & & & $-.120 *$ & $-.150^{*}$ & -.030 & -.040 & $-.146^{*}$ \\
\hline Maternal education & & & & & $.603^{*}$ & $.307^{*}$ & .011 & $.177^{*}$ \\
\hline Paternal education & & & & & & $.253^{*}$ & .028 & $.148^{*}$ \\
\hline Family income & & & & & & & .079 & .048 \\
\hline Age of child & & & & & & & & .005 \\
\hline
\end{tabular}

REVT = Receptive \& Expressive Vocabulary Test (Kim, Hong, Kim, Jang, \& Lee, 2009). ${ }^{*} p<.001$.

어휘 점수의 $10 \% \mathrm{ile}$ 구간 단위별로 7세 $\mathrm{PED}$ 의 분포를 분석한 결과, 7세 $\mathrm{PED}$ 의 $59.6 \%$ 가 3 세의 표현어휘 발달 $20 \%$ ile 미만이었으며, $80 \%$ 가 $30 \%$ ile 미만으로 나타났다(Table 4).

\section{학교수행력의 차이 분석 결과}

\section{기술통계 분석결과}

3세의 LT와 TD 집단이 7세 때에 나타낸 학교수행력 관련 변인들 의 평균점수 분석 결과, LT 집단은 '언어관련 학업수행력' 16.07 , '언 어 이외 학업수행력’ 21.34 , ‘학교적응력’ 138.92 , ‘집행기능’ 52.23 을 나타냈으며, TD 집단은 '언어관련 학업수행력' 16.77 , '언어 이외 학 업수행력' 21.78, ‘학교적응력' 139.81, ‘집행기능’ 51.77로 나타나 모 든 변인들에서 $\mathrm{LT}$ 집단이 TD 집단에 비하여 교사들의 긍정적인 평정이 낮게 나타났다(Table 5).

\section{변인 간 상관관계 분석결과}

종속변인들인 7세 때의 ‘언어관련 학업수행력', '언어 이외 학업 수행력, '학교적응력', ‘집행기능'과 종속변인들에 영향을 줄 수 있 는 3세 때의 모의 학력, 부의 학력, 가정의 월평균소득, 아동의 수용 어휘 백분위점수, 출생 순위, 아동 연령(월) 간의 이변량 상관관계 를 유의수준 .001에서 분석한 결과, 모든 종속변인 간에 상관이 유 의하였고, 모의 학력, 부의 학력 및 수용어휘 점수가 종속변인들과 유의한 상관을 보였다(Table 6).

\section{다변량공분산분석 결과}

종속변인 간의 상관이 모두 유의하고, 모의 학력, 부의 학력, 수 용어휘 점수가 종속변인들과 유의한 상관이 나타났으므로 세 가외 변인을 공변인으로 한 다변량공분산분석을 실시하여 집단 간 차 이를 검증하였다. 분석결과, '언어관련 학업수행력'에서 3 세의 LT 집단과 TD 집단 간의 차이가 유의하였으며 $\left(F_{(1,856)}=5.814, p<.05\right)$,
‘언어 이외 학업수행력' '학교적응력' 및 '집행기능'에서는 집단 간 차이가 유의하지 않았다.

\section{논의 및 결론}

본 연구는 우리나라 아동들을 대상으로 한 대규모의 종단자료 를 사용하여 3 세의 LT 아동의 출현율을 제시하고, 이들이 7세에 나 타내는 언어 및 학업 발달 예후를 분석하여 조기 언어중재의 필요 성을 제시하는 데 목적이 있었다. 이를 위해 3 세의 LT 아동들과 TD 아동들이 7세에 나타낸 표현어휘 발달 및 학교수행력을 비교 분석 하였다.

분석결과, 첫째, 우리나라 3 세 아동들 중 LT의 비율은 약 $16.6 \%$ 로 나타났으며, 남아와 여아의 비율은 각각 $59.2 \%$ 와 $40.8 \%$ 로 나타 났다. 3 세 이하의 '말늦은 아동'의 출현율에 대한 국외 선행연구들 도 대략 10-20\% 수준의 출현율을 보고하고 있다(Hammer et al., 2017; Klee, Schaffer, May, Membrino, \& Mougey, 1989; Rescorla, 1989). 성별 출현율도 연구마다 차이가 있으나 남아의 출현율이 여 아보다 높은 남아 우세적 경향은 대부분의 관련 연구들에서 일치 하는 결과이다.

둘째, 3세의 LT와 TD 집단이 7세 때에 나타낸 표현어휘 발달 예 후를 비교 분석한 결과, LT의 이력이 있는 아동들 중 약 $31 \%$ 가 7세 때에 표현어휘 발달 지체인 PED로 분류되었으며, 이는 3 세의 $\mathrm{TD}$ 아동들에 비해 3 배 이상 많았다. 3 세의 TD 아동들 중에서 $10 \%$ 가 량이 7세 $\mathrm{PED}$ 로 분류되었는데 세부 분석을 실시한 결과, 이들 대 부분인 $80 \%$ 의 아동들이 3 세 때 표현어휘 발달이 $30 \%$ ile 미만 수준 이었던 것으로 나타났다. 이러한 결과들은 3 세의 늦은 표현어휘 발 달이 7세까지 언어발달에 부정적인 영향을 미치고 있음을 강하게 시사한다. Rescorla 등(2000)은 3 세의 '말늦은 아동' 집단이 4 세에 표현어휘 수준은 정상 발달 범주에는 도달했으나 일반 발달 집단 
의 아동들에 비하여 현저하게 낮은 수준을 나타냈다고 보고하였 다. 2,3 세의 어휘력이 13 세의 어휘 수준에 대한 유의한 예측요인으 로 보고되었으며(Rescorla, 2005) 또한 3세의 '말늦은 아동' 집단이 17 세에 일반 발달 아동들에 비해 현저히 낮은 어휘수준을 나타냈 다는 보고도 있다(Rescorla, 2009). 본 연구결과는 이러한 선행연구 들을 지지하는 결과로써 초기의 어휘발달 지체가 상당 기간 동안 지속되거나악영향을 미칠 수 있음을 보여준다.

셋째, 학교수행력 관련 변인들에 대한 분석 결과, 읽기, 쓰기, 말 하기, 말 이해하기 항목의 '언어 관련 학업수행력'에서 3세 LT 집단 이 TD 집단보다 유의하게 낮은 수준을 보였다. Rice, Taylor와 $\mathrm{Zu}-$ brick (2008)은 영어를 사용하는 호주의 2 세 아동들을 대상으로 표 현어휘 발달이 $15 \%$ ile 이하인 late language emergence (LLE) 집단 과 LLE의 이력이 없는 집단 간의 7세 언어발달 수준을 비교 분석한 결과, 두 집단이 어휘에서는 유사한 수준이었으나, 말소리발달, 형 태 및 통사 영역에서는 LLE 집단이 유의하게 낮은 수준을 보였다고 보고하였다. Rescorla (2013)는 '말늦은 아동' 집단을 3세에서 17세 까지 15 년 동안 종단적으로 연구한 연구결과들을 종합한 결과, 3 세 의 '말늦은 아동'집단이 그러한 이력이 없는 아동들에 비하여 17세 까지 다양한 언어영역에서 지속적으로 낮은 수준을 보인 것으로 나타났다. 8-9세에는 특히 담화의 문법 구조, 이야기 문법, 듣기 이 해력 등의 상위언어 영역에서 비교 집단에 비해 현저히 낮은 수준 을 보였으며, 17 세에는 문법과 구어기억력에서 낮은 수준을 나타냈 다. 본 연구에서도 $\mathrm{LT}$ 집단이 $\mathrm{TD}$ 집단에 비해 7세의 '언어관련 학 교 수행력'에서 낮은 수행수준을 나타낸 결과는 선행연구들이 제 시한 바와 같이 어휘보다 높은 상위의 언어 영역에서 지속적인 문 제를 야기할 가능성이 높다는 결과와 일치한다. 본 연구에서 '언어 이외 학교 수행력' '집행기능', '학교 적응력'은 비록 다변량분석의 집단 간 차이는 유의하지 않았으나 $\mathrm{LT}$ 집단이 TD보다 낮은 평균 수준을 나타냈다. 2-3세의 LT의 이력이 언어 이외의 학업이나 행동 및 정서와 같은 다른 발달 영역에도 부정적인 영향을 미친다는 결 과는 최근 연구들에서 제시되고 있다. Hammer 등(2017)은 전체 약 9,600 명의 자료를 사용하여 영어를 사용하는 24 개월의 '말늦은 아동'의 이력이 48 개월 어휘발달 수준과 60 개월의 학교 수행력(읽 기, 수학, 행동척도)에 미치는 영향력에 대해 회귀분석을 실시한 결 과, 24 개월 '말늦은 아동'의 이력이 60개월의 읽기 관련, 수학 관련, 행동척도와 같은 학교수행력에서 부정적인 영향을 미치는 유의한 요인으로 나타났다. 국내 3 세 '말늦은 아동'의 7세 정서발달을 추적 연구한 Lee, Kim과 Hong (2018)에서도 ‘말늦은 아동' 집단이 사회 적 미성숙, 주의집중 문제와 규칙위반과 공격행동 같은 사회정서 영 역에서 일반 아동보다 유의하게 부정적인 수행을 보이는 것으로 나
타났다.

언어발달은 음운, 어휘, 문법, 담화, 문해 등의 영역이 지속적인 관 련성을 가지고 발달하는 분야이며, 언어는 곧 학업과 또래 관계, 정 서 및 사회성 발달에 결정적인 영향을 미치는 요인이다. 따라서 초 기의 표현어휘 수준의 발달 결함이 장기간에 걸쳐 언어뿐만 아니라 다양한 발달 영역에서 부정적인 영향을 미칠 가능성을 배제할 수 없다. 본 연구결과는 3세 이하의 연령에서 표현어휘 발달이 지체된 아동들 중에서 상당 비율의 아동들이 지속적으로 오랜 기간 동안 언어발달에서 결함을 나타내며, 학령기 이후에 학업뿐만 아니라 다른 학교 관련 행동까지도 부정적인 영향을 미칠 가능성이 높다 는 것을 보여주었다.

이처럼 발달 초기의 표현어휘 발달의 지체는 학령기 이후의 언어 를 포함한 주요 발달 영역의 결함의 야기할 수 있는 위험요인이다. 이는 단순히 표현어휘에서만 지체를 나타낼지라도 지속적인 관심 과 적절한 평가 및 적극적인 조기 언어중재를 고려할 필요가 있음 을 시사한다. 조기 언어중재는 아동들의 후일 발생 가능한 문제의 차단과 발생할 수 있는 부정적 문제의 정도를 경감시킬 수 있는 예 방적 차원에서 가장 효과적인 접근이 될 수 있다. 본 연구는 '말늦 은 아동'이 학령기에 나타내는 언어 및 학교 관련 수행력의 문제를 실증적으로 제시함으로써 이들에 대한 조기 평가와 중재에 대한 근거를 제시했다는 점에서 의의가 있다. 후속 연구로 말늦은 아동 의 언어발달 예후에 대한 예측 요인 분석, 조기 언어중재의 시작 시 기와 발달 예후 간의 관계 분석 그리고 학령기 후반 이후까지의 장 기간 추적 연구 등이 필요하다.

\section{REFERENCE}

Billeaud, F. P. (2003). Communication disorders in infants and toddlers: assessment and intervention. St. Louis, MO: Butterworth-Heinemann.

Dornbusch, S. M., Ritter, P. L., Leiderman, P. H., Roberts, D. F., \& Fraleigh, M. J. (1987). The relation of parenting style to adolescent school performance. Child Development, 58, 1244-1257.

Girolametto, L., Weitzman, E., Earle, C., Rescorla, L., \& Dale, P. S. (2013). From words to early sentences: Parent-implemented intervention for latetalking toddlers. In L. Rescorla \& P. S. Dale (Eds.), Late talkers: language development, interventions, and outcomes (pp. 261-282). Baltimore, MD: Paul H. Brookes Publishing.

Hammer, C. S., Morgan, P., Farkas, G., Hillemeier, M., Bitetti, D., \& Maczuga, S. (2017). Late talkers: a population-based study of risk factors and school readiness consequences. Journal of Speech, Language, and Hearing Research, 
60, 607-626.

Hong, G. H., \& Kim, Y. T. (2005). A longitudinal study of predictors for expressive vocabulary development of late-talkers. Korean Journal of Communication \& Disorders, 10, 1-24.

Jang, J. H. (2017). The effects of speech/language impairment on academic performance and school adjustment: a longitudinal study. Proceedings of the 8th International Conference on the Panel Study on Korean Children, 353-378.

Kim, E., Pae, Y., Jo, S., Lee, Y., Song, S., Lim, J., ..., \& Kim, E. (2016). The Panel Study on Korean Children II. Seoul: Korea Institute of Child Care and Education.

Kim, J. M., \& Lee, S. H. (2007). The effect of "It Takes Two to Talk" program on communicative abilities of the children with developmental language delay and their parents' behaviors. Korean Journal of Communication \& Disorders, 12, 607-624.

Kim, S., Lee, S., \& Hong, G. (2017). A longitudinal study of phonological development in Korean late-talkers. Korean Journal of Speech Sciences, 9, 115122.

Kim, Y. T., Hong, G. H., Kim, K. H., Jang, H. S., \& Lee, J. Y. (2009). Receptive \& expressive vocabulary test (REVT). Seoul: Seoul Community Rehabilitation Center.

Klee, T., Schaffer, M., May, S., Membrino, I., \& Mougey, K. (1989). A comparison of the age-MLU relation in normal and specifically language-impaired preschool children. Journal of Speech and Hearing Disorders, 54, 226-233.

Lee, S., Kim, S. J., \& Hong, G. H. (2018). Longitudinal study of socio-emotional development in Korean late-talkers. Journal of Speech-Language \& Hearing Disorders, 27, 155-163.

Lee, Y. H. (2015). The meaning of early intervention: a parent's experience and reflection on interactions with professionals using a phenomenological ethnographic approach. International Journal of Qualitative Studies on Health and Well-Being, 10, 25891.

Leonard, L. B. (1998). Children with specific language impairment. Cambridge, MA: MIT Press.

Manhardt, J., \& Rescorla, L. (2002). Oral narrative skills of late talkers at ages
8 and 9. Applied Psycholinguistics, 23, 1-21.

Nicholas, J. G., \& Geers, A. E. (2003). Personal, social, and family adjustment in school-aged children with a cochlear implant. Ear and Hearing, 24, 69S$81 S$.

Panel Study on Korean Children. (2013). Study overview. http://panel.kicce. re.kr/

Panel Study on Korean Children. (2013). Study questionnaire. http://panel. kicce.re.kr/kor/publication/01.jsp

Rescorla, L. (1989). The Language Development Survey: a screening tool for delayed language in toddlers. Journal of Speech and Hearing Disorders, 54, 587-599.

Rescorla, L. (2002). Language and reading outcomes to age 9 in late-talking toddlers. Journal of Speech, Language, and Hearing Research, 45, 360-371.

Rescorla, L. (2005). Age 13 language and reading outcomes in late-talking toddlers. Journal of Speech, Language, and Hearing Research, 48, 459-472.

Rescorla, L. (2009). Age 17 language and reading outcomes in late-talking toddlers: support for a dimensional perspective on language delay. Journal of Speech, Language, and Hearing Research, 52, 16-30.

Rescorla, L. (2013). Late-talking toddlers: a 15-year follow-up. In L. Rescorla \& P. S. Dale (Eds.), Late talkers: language development, interventions, and outcomes (pp. 219-240). Baltimore, MD: Paul H. Brookes Publishing.

Rescorla, L., Dahlsgaard, K., \& Roberts, J. (2000). Late-talking toddlers: MLU and IPSyn outcomes at 3;0 and 4;0. Journal of Child Language, 27, 643-664.

Rescorla, L., \& Dale, P. S. (2013). Late talkers: language development, interventions, and outcomes. Baltimore, MD: Paul H. Brookes Publishing.

Rice, M. L., Taylor, C. L., \& Zubrick, S. R. (2008). Language outcomes of 7-yearold children with or without a history of late language emergence at 24 months. Journal of Speech, Language, and Hearing Research, 51, 394-407.

Rossetti, L. M. (2001). Communication intervention: birth to three. San Diego, CA: Cengage Learning.

Shin, H. J., \& Lee, E. J. (2015). Phonological characteristics of late-talkers through phonological whole-word analysis. Communication Sciences \& Disorders, 20, 157-165.

Shipley, K. G. (1992). Interviewing and counseling in communicative disorders: principles and procedures. New York, NY: Merrill. 
Appendix 1. 학업수행력 변인별 문항 예시

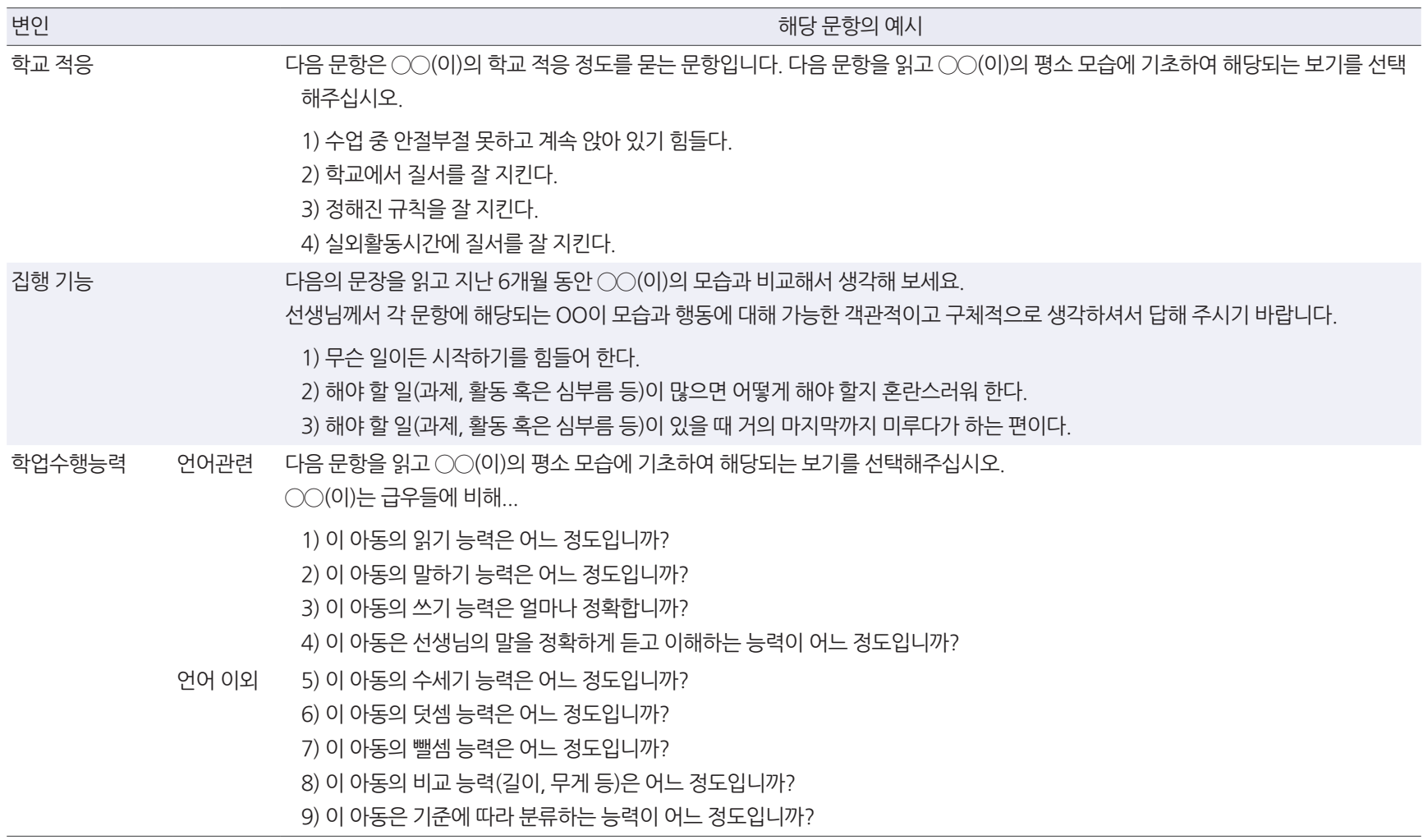




\section{국문초록}

\section{3세 말늦은 아동의 7 세 언어발달 및 학교수행력 종단연구}

홍경훈(교수, 제1저자) · 이수향(교수, 교신저자) · 김수진(교수)

나사렛대학교 재활치료학부 언어치료학전공

배경 및 목적: 본 연구는 3세의 ‘말늦은 아동(LT)'의 출현율과 ‘말늦은 아동’ 집단과 ‘일반 발달 아동(TD)’ 집단이 7세에 언어발달과 학 교수행력에서 나타낸 집단 간 차이를 분석하였다. 방법: 연구 대상자는 한국아동패널 연구에 참여한 1,342 명이었다. 이들을 3 세 때 REVT의 표현어휘 점수를 기준으로 $10 \%$ ile 미만을 LT 그리고 그 이상을 TD 집단으로 분류하였다. 이 두 집단의 REVT 표현어휘와 학교 수행력이 7세에 종단적으로 측정되었다. 다변량공분산분석을 실시하여 두 집단 간의 차이를 검증하였다. 결과: 본 연구의 결과는 다음 과 같다. LT의 출현율은 $16.6 \%$ 이었으며, LT의 $31.4 \%$ 그리고 TD 아동의 $10.1 \%$ 가 7세 때의 표현어휘 수준이 또래 집단의 $10 \% \mathrm{ile}$ 미만으로 나타났다. 7세의 표현어휘 및 언어 관련 학업수행력(읽기, 쓰기, 말하기, 듣기) 점수는 LT가 TD보다 유의한 차이를 나타냈다. 논의 및 결 론: 이 연구의 결과는 발달 초기 표현어휘 발달의 지체가 언어발달과 학교수행력에 부정적인 예후를 야기하는 위험요인이 될 수 있음을 시사한다. LT의 후일 언어발달 및 학교수행력의 결함을 효과적으로 예방하기 위해서는 조기에 언어중재가 고려되어야 한다.

핵심어: 말늦은 아동, 종단연구, 표현어휘 발달, 학교수행력

본 연구는 2018학년도 나사렛대학교 교내연구비 지원에 의하여 수행되었음.

\section{참고문헌}

김수진, 이수향, 홍경훈(2017). 말늦은 아동의 말소리 발달 종단 연구. 말소리와 음성과학, 9, 115-122.

김영태, 홍경훈, 김경희, 장혜성, 이주연(2009). 수용·표현어휘력검사(REVT). 서울: 서울장애인종합복지관.

김은설, 배윤진, 조숙인, 이예진, 송신영, 임준범, 박은영, 김신경, 김은정(2016). 한국아동패널II. 서울: 육아정책연구소.

김정미, 이수향(2007). 'It Takes Two to Talk' 부모교육프로그램이 언어발달지체아동의 의사소통과 부모의 행동에 미치는 효과. 언어청각장애연구,

$12,607-624$.

신화정, 이은주(2015). 단어단위 음운분석에 의한 말 늦은 아동의 음운 특성. Communication Sciences \& Disorders, 20, 157-165.

이수향, 김수진, 홍경훈(2018). 말늦은 아동의 사회 정서 발달 종단연구. 언어치료연구, 27, 155-163.

장종호(2017). 학령전기의 말언어수행이 학령기의 학업수행과 학교적응에 미치는 영향. 한국아동패널 국제학술대회자료집, 353-378.

한국아동패널(2013). 한국아동패널 소개.http://panel.kicce.re.kr

한국아동패널(2013). 한국아동패널 질문지.http://panel.kicce.re.kr/kor/publication/01.jsp

홍경훈, 김영태(2005). 종단연구를 통한 '말늦은아동 (late-talker)'의 표현어휘발달 예측요인 분석. 언어청각장애연구, 10, 1-24. 